\title{
PENGARUH KUALITAS PELAYANAN TERHADAP VOLUME PENJUALAN PADA MINI MARKET MINAMART'90 BANDUNG
}

\author{
Indra Sasangka \\ Rahmat Rusmayadi \\ STIE Muhammadiyah Bandung \\ Jl. Karapitan No.143 Bandung
}

\begin{abstract}
Abstrak
Dalam menenuhi permintaan kebutuhan masyarakat, perusahaan harus menghadapi persaingan yang ketat baik untuk perusahaan yang sejenis maupun yang berbeda sama sekali. Maka Pelayanan kepada konsumen menjadi sangat penting artinya bagi kehidupan suatu perusahaan, karena tanpa konsumen, maka tidak akan terjadi transaksi jual beli diantara keduanya. sehingga menuntut perusahaan untuk melakukan persaingan yang sangat ketat.Untuk dapat terus bertahan perusahaan dituntut untuk melakukan strategi bauran pemasaran dengan baik. Untuk meningkatkan volume penjualan perusahaan harus mampu memasarkan produknya dengan baik. Kegiatan pemasaran perusahaan akansangat berpengaruh terhadap volume penjualan. Meningkatnya volume penjualan dapat dicapai jika strategi bauran pemasaran diterapkan dalamperusahaan dengan tepat.

Metode yang digunakan pada penelitian ini adalah metode deskriptif yang merupakan cara ilmiah untuk mendapatkan data dengan tujuan dan dengan kegunaan tertentu. Dan cara ilmiah ini berarti kegiatan penelitian itu didasarkan pada ciri-ciri keilmuan yang rasional, empiris dan sistematis. Dikatakan rasional itu karena kegiatan penelitian itu dilakukan dengan cara-cara yang masuk akal, sehingga dapat terjangkau oleh penalaran manusia. Empiris berarti cara-cara yang dilakukan itu dapat diamati oleh indera manusia, dan mengetahui cara-cara yang digunakan. Sedangkan sistematis itu berarti proses yang digunakan dalam penelitian itu menggunakan langkah-langkah tertentu yang bersifat logis.

Dari hasil penelitian ini diperoleh bentuk persamaan regresi linear sederhana sebagai berikut : $\mathrm{Y}=38.496+0.881 \mathrm{X}$, artinya bahwa peningkatan aspek penetapan harga akan mengakibatkan peningkatan terhadap volume penjualan. Dengan kata lain setiap peningkatan aspek kualitas pelayanan sebesar 1 akan diikuti dengan peningkatan aspek volume penjualan sebesar 0.881. Demikian pula sebaliknya, jika aspek kualitas pelayanan mengalami penurunan sebesar 1 maka aspek volume penjualan pasti akan cenderung mengalami penurunan sebesar 0.881 .

Penelitian ini menyimpulkan bahwa besarmya kontribusi pengaruh variabel kualitas pelayanan (kehandalan, ketanggapan, jaminan, empati dan bukti fisik) terhadap kualitas pelayanan pada minimarket Minamart'90 adalah sebesar $67 \%$. Sementara sisanya sebesar $33 \%$ dipengaruhi oleh variabel lain yang tidak diteliti.
\end{abstract}

Kata kunci : Kualitas Pelayanan dan Volume Penjualan 


\section{PENDAHULUAN}

Seiring dengan perkembangan ekonomi di Indonesia saat ini, proses pemenuhan kebutuhan hidup yang menyangkut kebutuhan primer dan kebutuhan sekunder meningkat terus menerus. Hal ini menyebabkan manusia yang berperan sebagai konsumen menginginkan proses pembelian barangbarang kebutuhan sehari-hari tercipta lebih mudah, dimana saat ini kita mengenalnya sebagai tempat belanja yang mudah dan langsung, dan di kenal dengan sebutan minimarket dalam sekala kecil dan supermarket hingga hypermarket dalam sekala yang lebih besar.

Dalam menenuhi permintaan kebutuhan masyarakat, perusahaan harus menghadapi persaingan yang ketat baik untuk perusahaan yang sejenis maupun yang berbeda sama sekali. Maka Pelayanan kepada konsumen menjadi sangat penting artinya bagi kehidupan suatu perusahaan, karena tanpa konsumen, maka tidak akan terjadi transaksi jual beli diantara keduanya. sehingga menuntut perusahaan untuk melakukan persaingan yang sangat ketat.Untuk dapat terus bertahan perusahaan dituntut untuk melakukan strategi bauran pemasaran dengan baik. Menurut Kasmir dan Jakfar (2012:47), pemasaran dapat pula diartikan sebagai upaya untuk menciptakan dan menjual produk kepada berbagai pihak dengan maksud tertentu.

Tujuan menggunakan konsep pemasaran adalah untuk memperbaiki hubungan konsumen karena hubungan yang lebih baik sangat menguntungkanbagi perusahaan, dan dapat meningkatkan laba. Untuk dapat meningkatkan laba perusahaan harus dapat meningkatkan volume penjualan. Menurut BasuSwastha (2007:17), volume penjualan yang menguntungkan harus menjadi tujuan perusahaan, dan bukannya volume untuk kepentingan volume itusendiri.

Untuk meningkatkan volume penjualan perusahaan harus mampu memasarkan produknya dengan baik. Kegiatan pemasaran perusahaan akansangat berpengaruh terhadap volume penjualan. Meningkatnya volume penjualan dapat dicapai jika strategi bauran pemasaran diterapkan dalamperusahaan dengan tepat.

Di zaman globalisasi ini persaingan bisnis telah membuat berbagai perusahaan berlomba untuk merebut dan mempertahankan pangsa pasarnya dengan menanamkan modalnya dibidang usaha retail serta memperluasnya, sehingga mendorong pemerintah untuk mengeluarkan sebuah peraturan yang memperhitungkan kondisi sosial ekonomi masyarakat.

Dengan munculnya usaha-usaha retail baru tersebut tentu dapat mempengaruhi pangsa pasar yang sudah ada. Untuk menjaga timbulnya persaingan yang tidak sehat antara toko modern dan pasar tradisional melalui Peraturan Presiden Nomor 112 Tahun 2007 tentang pengaturan lokasi Minimarket dengan Pasar Tradisional, diantaranya disebutkan :

- Dalam Pasal 4 ayat (1) Perpres 112/2007, disebutkan setiap toko modern wajib memperhitungkan kondisi sosial ekonomi mayarakat sekitar serta jarak antara toko modern dengan pasar tradisional yang ada.

dalam Pasal 5 ayat 4, disebutkan bahwa minimarket boleh berlokasi pada setiap sistem jaringan jalan, termasuk sistem jaringan jalan lingkungan pada kawasan pelayanan lingkungan (perumahan) di dalam kota / perkotaan.

Berdasarkan peraturan tersebut di atas artinya, minimarket masih bisa membuka gerai hingga ke wilayah pemukiman warga. 
Hal ini tentu mendorong para pengusaha retail untuk melakukan peningkatan pelayanan terhadap konsumen serta menetapkan strategi pelayanan yang tepat agar para konsumen yang telah dikuasai dapat dipertahankan atau bisa meningkatkan jumlah konsumen yang sudah ada tersebut.

Para penjual harus bisa menemukan berbagai strategi yang tepat untuk mencapai keunggulan yang kompetitif, dengan harapan bisa mempertahankan pasar dan memenangkan persaingan. Keadaan ini menuntut perusahaan untuk selalu melakukan inovasi di setiap layanan yang akan mereka berikan kepada konsumen dengan mengutamakan kenyamanan yang diterima konsumen setiap kali berkunjung dan berbelanja.

Persaingan bisnis ritel Minimarket khususnya di kota Bandung saat ini cukup ketat. Berdasarkan data dari Dinas Koperasi UKM, Perindustrian, dan Perdagangan (Diskoperindag), jumlah minimarket di Kota Bandung hingga tahun 2011 berjumlah 357 buah minimarket. Sehingga dapat kita temui minimarket hampir disetiap lokasi di kota Bandung, selain dengan posisi minimarket tidaklah berjauhan juga berdekatan dengan pasar-pasar tradisional.

Tabel 1.

Data Sarana Perdagangan Kota Bandung Tahun 2009-2011

\begin{tabular}{|c|c|c|c|c|}
\hline \multirow{2}{*}{ No } & \multirow{2}{*}{$\begin{array}{c}\text { Jenis sarana } \\
\text { perdagangan }\end{array}$} & \multicolumn{3}{|c|}{ Jumlah } \\
\cline { 3 - 5 } & & 2009 & 2010 & 2011 \\
\hline 1 & Mall & 47 & 41 & 28 \\
\hline 2 & Supermarket & 51 & 40 & 26 \\
\hline 3 & Minimarket & 229 & 316 & 357 \\
\hline 4 & Hypermarket & 2 & 5 & 8 \\
\hline 5 & Perkulakan & 5 & 3 & 3 \\
\hline 6 & Departemen store & 11 & 13 & 16 \\
\hline 7 & Factory outlet & 98 & 98 & 98 \\
\hline 8 & Distribusi store & 135 & 135 & 135 \\
\hline
\end{tabular}

Sumber : Data Dinas KUKM dan industri perdagangan Kota Bandung, 2011 
Dari fakta di atas, tentu saja menuntut para produsen mini market untuk menyiapkan strategi bagaimana cara meningkatkan rasa kenyamanan (convenience) yang memuaskan para konsumen, terutama dengan konsumen minimarket yang ada di kota Bandung sangat heterogen. Setiap konsumen mempunyai hak untuk dapat memilih yang mereka sukai, apabila mereka tidak suka dengan satu minimarket mereka berhak untuk mencari minimarket yang lain dengan mengevaluasi atributatribut mana yang tepat dan kurang tepat untuk mereka.

Seperti halnya Minimarket Minamart'90 yang terletak di Jl. Nilem No. 9 Buahbatu Bandung, yang saat ini tengah bersaing dengan toko-toko pengecer atau minimarket lain yang jumlahnya semakin bertambah. Minimarket Minamart'90 merupakan perusahaan eceran yang menjual beraneka ragam kebutuhan pribadi dan konsumsi rumah tangga sehari-hari yang di miliki oleh Pimpinan Cabang Muhammadiyah Lengkong Kota Bandung dan telah berdiri sejak tahun 2008, namun untuk dapat memberikan layanan yang lebih baik kepada konsumen atau pelanggan, salah satunya adalah dengan memperhatikan keluhan yang disampaikan pelanggan secara langsung.

Terdapat data keluhan pelanggan selama tiga tahun, yaitu tahun 2013, tahun 2014 dan tahun 2015 yang dicatat dalam buku keluhan Toko dari Minimarket Minamart'90, sebagaimana tercermin dalam tabel di bawah ini.

Tabel 2.

Data Keluhan Pelanggan

Mini Market Minamart'90 tahun 2013-2015

\begin{tabular}{|c|c|c|c|}
\hline Keterangan & $\mathbf{2 0 1 3}$ & $\mathbf{2 0 1 4}$ & $\mathbf{2 0 1 5}$ \\
\hline Stock barang kosong & 8 & 10 & 6 \\
\hline Harga dikasir tidak sesuai dengan harga di rak & 3 & 7 & 4 \\
\hline Cacat kemasan & 7 & 9 & 5 \\
\hline Tempat parker & 11 & 2 & 8 \\
\hline $\begin{array}{c}\text { Kurang ramahny para pramuniaga kepada } \\
\text { pelanggan }\end{array}$ & 4 & 8 & 6 \\
\hline Jumlah keluhan & 33 & 36 & 29 \\
\hline
\end{tabular}

Sumber : Data Keluhan pelanggan Mini Market Minamart'90

Dari informasi dapat dijadikan bahan evaluasi tentang masih kurangnya layanan yang diberikan oleh pihak Minimarket Minamart'90 kepada pelanggannya. Kualitas pelayanan tentu dapat memberikan kontribusi kepada perusahaan dalam meningkatkan pendapatan jangka panjangnya yaitu pada sejauh mana kemampuan perusahaan atau organisasi mampu melayani atau memberi pelayanan secara maksimal kepada para pelanggannya.

Dengan adanya keluhan pelanggan terhadap pelayanan minimarket minamart'90, maka akan berpengaruh pada penjualan di Minimarket Minamart'90 yang 
di tunjukan dengan jumlah penjualan yang tidak mengalami peningkatan yang signifikan, bahkan cenderung terjadi penurunan sebagaimana tercantum pada tabel dibawah ini

Tabel 3.

Total Volume Penjualan

\begin{tabular}{|l|c|c|c|}
\hline \multicolumn{1}{|c|}{ PERINCIAN LABA RUGI } & $\mathbf{2 0 1 3}$ & $\mathbf{2 0 1 4}$ & $\mathbf{2 0 1 5}$ \\
\hline PENJUALAN BERSIH & $507,097,650.00$ & $478,372,100.00$ & $445,511,600.00$ \\
\hline HARGA POKOK PENJUALAN & $432,368,476.79$ & $404,649,940.00$ & $381,223,254.02$ \\
\hline LABA KOTOR & $74,729,173.21$ & $73,722,160.00$ & $64,288,345.98$ \\
\hline Margin \% & 14.72 & 15.41 & 14.44 \\
\hline SPD & $1,451,545.81$ & $1,341,954.82$ & $1,305,407.83$ \\
\hline STD & 102.51 & 91.07 & 81.91 \\
\hline APC & $14,218.63$ & $14,726.06$ & $15,940.56$ \\
\hline HARI BUKA & 29.25 & 29.75 & 28.58 \\
\hline LPP & $82,835,897.92$ & $86,820,970.08$ & $36,732,391.75$ \\
\hline DSI & 57.72 & 65.19 & 29.77 \\
\hline
\end{tabular}

Sumber : Data Penjualan Minimarket Minamart'90

Kelima dimensi kualitas layanan ini menjadi kesan awal yang diterima pelanggan apabila mengunjungi perusahaan tersebut. Persepsi puas atau tidak puas bergantung pada kualitas layanan yang diberikan oleh perusahaan tersebut. (Kusumawatie, 2005) dalam situasi persaingan yang semakin kompleks, kebutuhan dan keinginan pelanggan selalu meningkat diikuti dengan tingkat kemampuan tertentu dari pelanggan. Semakin tinggi tingkat kemampuan pelanggan maka semakin tinggi pula tuntutan yang diminta dalam pelayanan.

Apabila harapannya terpenuhi pelanggan akan merasa puas, sehingga akan melakukan pembelian ulang, selain itu pelanggan yang puas akan membantu untuk mendapatkan pelanggan baru yang mendorong peningkatan volume penjualan.

KERANGKA TEORITIS \& HIPOTESIS Volume Penjualan Definisi Volume volume/vo $\cdot \mathrm{lu} \cdot \mathrm{me} / \mathrm{n} 1$ isi atau besarnya benda dalam ruang; 2 tingkat kenyaringan atau kekuatan (tentang bunyi, suara, dan sebagainya); 3banyaknya; besarnya; bobot (tentang ekspor, pekerjaan, dan sebagainya): -- ekspor tahun ini melebihi -. ekspor tahun yang lalu; -- pekerjaan meningkat pada akhir tahun anggara. (http://kamusbahasaindonesia.org/volume)

Volume atau bisa juga disebut kapasitas adalah penghitungan seberapa banyak ruang yang bisa ditempati dalam suatu objek. Objek itu bisa berupa benda yang beraturan ataupun benda yang tidak beraturan. Benda yang beraturan misalnya kubus, balok, silinder, limas, kerucut, dan bola. Benda yang tidak beraturan misalnya batu yang ditemukan di jalan. Volu [..]Sumber: id.wikipedia.org

\section{Definisi Penjualan}

Sumber pendapatan suatu perusahaan adalah berasal dari penjualan, karena dengan adanya penjualan dapat mengubah posisi harta perusahaan. Penjualan 
merupakan puncak kegiatan dalam seluruh kegiatan perusahaan. Berikut ini akan dikemukakan definisi penjualan menurut para ahli.

Menurut Soemarso (2002:226), yang dimaksud dengan penjualan adalah: "Penjualan adalah jumlah yang dibebankan kepada pembeli karena penjualan barang dan jasa baik secara kredit maupun secara tunai".

Adapun Menurut Basu Swastha DH (2004 : 403) penjualan adalah interaksi antara individu saling bertemu muka yang ditujukan untuk menciptakan, memperbaiki, menguasai atau mempertahankan hubungan pertukaran sehingga menguntungkan bagi pihak lain.

Menurut Basu Swastha dalam Irwan Sahaja (2014), penjualan adalah suatu proses pertukaran barang atau jasa antara penjual dan pembeli. Maka penjualan dapat diartikan juga sebagai usaha yang dilakukan manusia untuk menyampaikan barang bagi mereka yang memerlukan dengan imbalan uang menurut harga yang telah ditentukan atas persetujuan bersama.

Sumber pendapatan suatu perusahaan adalah berasal dari penjualan, karena dengan adanya penjualan dapat mengubah posisi harta perusahaan. Menurut Kusnadi (2009 : 19), menjelaskan bahwa "Penjualan (sales) adalah sejumlah uang yang dibebankan kepada pembeli atas barang atau jasa yang dijual". bahwa :

Winardi (2003 : 246) mengatakan

"Penjualan (selling) adalah suatu Transaksi hak atas benda-benda, jadi sasarang penjualan yaitu mengalihkan barang-barang dan jasa-jasa dari tangan produsen ketangan konsumen dengan harga yang layak”.

\section{Tujuan Penjualan}

Kemampuan perusahaan dalam menjual produknya menentukan keberhasilan dalam mencari keuntungan, apabila perusahaan tidak mampu menjual maka perusahaan akan mengalami kerugian.

Menurut Basu Swastha DH (2004 : 404) tujuan umum penjualan dalam perusahaan yaitu :

1) Mencapai volume penjualan

2) Mendapatkan laba tertentu

3) Menunjang pertumbuhan perusahaan

\section{Faktor-faktor yang mempengaruhi Penjualan}

Aktivitas penjualan banyak dipengaruhi oleh faktor yang dapat meningkatkan aktivitas perusahaan, oleh karena itu manajer penjualan perlu memperhatikan faktor-faktor yang mempengaruhi penjualan. Faktor-faktor yang mempengaruhi penjualan menurut Basu Swastha (2005) sebagai berikut :

1) Kondisi dan Kemampuan Penjual Kondisi dan kemampuan terdiri dari pemahaman atas beberapa masalah penting yang berkaitan dengan produk yang dijual, jumlah dan sifat dari tenaga penjual adalah:

a) Jenis dan karakteristik barang atau jasa yang ditawarkan

b) Harga produk atau jasa

c) Syarat penjualan, seperti:

pembayaran, pengiriman

2) Kondisi Pasar

Pasar mempengaruhi kegiatan dalam transaksi penjualan baiksebagai kelompok pembeli atau penjual. Kondisi pasar dipengaruhi oleh beberapa faktor yakni : jenis pasar, kelompok pembeli, daya beli, frekuensi pembelian serta keinginan dan kebutuhannya.

3) Modal 
Modal atau dana sangat diperlukan dalam rangka untuk mengangkut barang dagangan ditempatkan atau untuk membesar usahanya. Modal perusahaan dalam penjelasan ini adalah modal kerja perusahaan yang digunakan untuk mencapai target penjualan yang dianggarkan, misalnya dalam menyelenggarakan stok produk dan dalam melaksanaan kegiatan penjualan memerlukan usaha seperti alat transportasi, tempat untuk menjual, usaha promosi dan sebagainya.

4) Kondisi Organisasi Perusahaan

Pada perusahan yang besar, biasanya masalah penjualan ini ditangani oleh bagian tersendiri, yaitu bagian penjualan yang dipegang oleh orangorang yang ahli dibidang penjualan.

5) Faktor-faktor lain

Faktor-faktor lain seperti periklanan, peragaan, kampanye, dan pemberian hadiah sering mempengaruhi penjualan karena diharapkan dengan adanya faktor-faktor tersebut pembeli akan kembali membeli lagi barang yang sama.

Berdasarkan uraian di atas dapat disimpulkan bahwa ada beberapa faktor yang mempengaruhi kegiatan penjualan, yaitu: kondisi dan kemampuan penjualan, kondisi pasar, modal, kondisi organisasi perusahaan, dan faktor-faktor lain.

Aktifitas utama perusahaan selain produksi adalah penjualan. Aktifitas penjualan ini harus dapat dikendalikan, disebabkan kegiatan penjualan ini selalu mengalami perubahan sesuai kondisi atau permintaan pasar. Jika tidak dikendalikan penurunan volume penjualan dapat menyebabkan laba yang diperoleh perusahaan menjadi tidak maksimal.

Menurut Arman Hakim Nasution, dkk (2006: 158), bahwa "Penjualan adalah suatu kegiatan penghubung antara perusahaan dengan konsumen untuk merealisasikan tujuan terakhir pemasaran”.

\section{Volume Penjualan}

Dalam suatu perusahaan tujuan pemasaran adalah untuk meningkatkan volume penjualan yang menguntungkan dalam arti dapat menghasilkan pendapatan secara optimal dan meningkatkan laba. Berikut ini akan dikemukakan definisi volume penjualan menurut para ahli, yaitu:

Karim (2014 : 423) mengungkapkan beberapa hal yang berkaitan dengan volume penjualan yaitu :

"volume penjualan menurut Asri (1991:52) adalah jumlah unit penjualan nyata perusahaan dalam satu periode tertentu". Jadi penjualam dapat dikatakan sebagai hasil kegiatan penjualan yang di ukur dengan satuan.

Menurut Schiffan (2005:118), volume penjualan adalah tingkat penjualan yang diperoleh perusahaan untuk periode tertentu dalam satuan (unit/total/rupiah).

Menurut Kotler yang dikutip swasta dan Irawan (2003:404), menyimpulkan bahwa ada be berapa indikator dari volume penjualan adalah sebagai berikut :

1. Mencapai volume penjualan tert entu;

2. Mendapatkan laba tertentu;

3. Menunjang pertumbuhan perusahaan.

\section{Kualitas Pelayanan}

Kualitas pelayanan dapat diartikan sebagai upaya pemenuhan kebutuhan dan keinginan konsumen serta ketepatan penyampaiannya dalam mengimbangi harapan konsumen(Tjiptono, 2007).

Kualitas pelayanan (service quality) dapat diketahui dengan cara membandingkan persepsi para konsumen 
atas pelayanan yang nyata-nyata mereka terima / peroleh dengan pelayanan yang sesungguhnya mereka harapkan / inginkan terhadap atribut-atribut pelayanan suatu perusahaan. Jika jasa yang diterima atau dirasakan (perceived service) sesuai dengan yang diharapkan, maka kualitas pelayanan dipersepsikan baik dan memuaskan, jika jasa yang diterima melampaui harapan konsumen, maka kualitas pelayanan dipersepsikan sangat baik dan berkualitas.Sebaliknya jika jasa yang diterima lebih rendah daripada yang diharapkan, maka kualitas pelayanan dipersepsikan buruk..

Dalam persaingan antar minimarket yang semakin tajam kualitas pelayanan merupakan suatu strategi yang digunakan untuk meningkatkan kepuasan konsumen dan untuk menilai kualitas suatu pelayanan dalam riset pemasaran digunakan suatu model yang dikenal dengan model SERVQUAL yang dikembangkan Parasuraman dkk dalam Sabihaini (2002) yang meliputi lima dimensi, yaitu:

1. Reliability (kehandalan), yaitu kemampuan untuk memberikan layanan yang dijanjikan dengan segera, akurat, dan memuaskan.

2. Responsiveness (daya tanggap) yaitu kemampuan para karyawan untuk membantu para pelanggan dan memberikan layanan dengan tanggap.

3. Assurance (jaminan kepastian) yaitu kemampuan, kesopanan dan sifat dapat dipercaya yang dimiliki oleh para staf, bebas dari bahaya, resiko dan keraguraguan.

4. Empathy (empati) yaitu kemudahan dalam melakukan hubungan, komunikasi yang baik, perhatian pribadi, dan memahami kebutuhan pelanggan.
5. Tangibles (bukti langsung) yaitu fasilitas fisik, perlengkapan, pegawai dan sarana komunikasi

Menurut Tjiptono (1998) kualitas pelayanan memiliki hubungan yang erat dengan kepuasan pelanggan. Kualitas pelayanan memberikan suatu dorongan kepada pelanggan untuk menjalin ikatan hubungan yang kuat dengan perusahaan. Dengan demikian perusahaan dapat meningkatkan Volume penjualan disebabkan pengalaman pelanggan yang menyenangkan dan meminimumkan atau meniadakan pengalaman pelanggan yang kurang menyenangkan. Pada gilirannya kualitas pelayanan dapat menciptakan kesetiaan atau loyalitas pelanggan kepada perusahaan serta mendorong peningkatan volume penjualan

Dari definisi-definisi tentang kualitas pelayanan tersebut dapat disimpulkan bahwa kualitas pelayanan adalah segala bentuk aktivitas yang dilakukan oleh perusahaan guna memenuhi harapan konsumen. Pelayanan dalam hal ini diartikan sebagai jasa atau service yang disampaikan oleh pemilik jasa yang berupa kemudahan, kecepatan, hubungan, kemampuan dan keramahtamahan yang ditujukan melalui sikap dan sifat dalam memberikan pelayanan untuk kepuasan konsumen.

Kualitas pelayanan (service quality) dapat diketahui dengan cara membandingkan persepsi para konsumen atas pelayanan yang nyata-nyata mereka terima/peroleh dengan pelayanan yang sesungguhnya mereka harapkan terhadap atribut-atribut pelayanan suatu perusahaan.

Hubungan antara produsen dan konsumen menjangkau jauh melebihi dari waktu pembelian ke pelayanan purna jual, kekal abadi melampaui masa kepemilikan produk. Perusahaan menganggap konsumen sebagai raja yang harus dilayani dengan baik, 
mengingat dari konsumen tersebut akan memberikan keuntungan pada perusahaan untuk terus hidup.

\section{METODE PENELITIAN}

Merupakan rancangan tentang bagaimana suatu penelitian dilakukan dengan menggunakan metode tertentu. Metode penelitian merupakan cara kerja untuk dapat memahami suatu objek penelitian yang akan memandu peneliti tentang bagaimana urut-urutan penelitian dilakukan yang juga meliputi teknik dan prosedur yang digunakan dalam penelitian. Menurut Sugiyono (2006:3) metode penelitian dapat diartikan :

Sebagai cara ilmiah untuk mendapatkan data yang valid dengan tujuan dapat ditemukan, dibuktikan dan dikembangkan suatu pengetahuan sehingga pada gilirannya dapat digunakan untuk memahami, memecahkan, dan mengantisipasi masalah dalam bidang bisnis.

Dilihat dari tujuan penelitiannya, jenis penelitian ini dapat dikategorikan sebagai penelitian deskriptif analitis, yaitu suatu metode penelitian yang menggambarkan atau menjelaskan data yang sifatnya aktual dan dilanjutkan dengan menganalisis untuk mencari hubungan, kaitan, dan pengaruh antara variabel yang satu dengan variabel yang lain.

Metode penelitian ini merupakan cara ilmiah untuk mendapatkan data dengan tujuan dan dengan kegunaan tertentu. Dan cara ilmiah ini berarti kegiatan penelitian itu didasarkan pada ciri-ciri keilmuan yang rasional, empiris dan sistematis. Dikatakan rasional itu karena kegiatan penelitian itu dilakukan dengan cara-cara yang masuk akal, sehingga dapat terjangkau oleh penalaran manusia. Empiris berarti cara- cara yang dilakukan itu dapat diamati oleh indera manusia, dan mengetahui cara-cara yang digunakan. Sedangkan sistematis itu berarti proses yang digunakan dalam penelitian itu menggunakan langkahlangkah tertentu yang bersifat logis.

Sumber utama sebuah penelitian adalah data, karena dapat memberikan gambaran tentang keadaan yang ada pada objek penelitian. Data tersebut nantinya dapat digunakan sebagai dasar analisis penelitian setelah sebelumnya diolah dan diinterprestasikan, kemudian diadakan perbandingan-perbandingan antara teoriteori yang ada dengan pelaksanaannya, sehingga peneliti dapat menentukan bagaimana cara pemecahan masalah yang dihadapi oleh objek yang sedang diteliti.

Data yang diperoleh melalui penelitian itu adalah data empiris (teramati) yang mempunyai kriteria-kriteria tertentu yang valid. Valid berarti menunjukkan derajat ketepatan antara data yang sesungguhnya terjadi pada objek dengan data yang dapat dikumpulkan oleh peneliti. Menurut Sugiyono (2009:21) "Deskriptif adalah metode yang digunakan untuk menggambarkan atau menganalisis suatu hasil penelitian tetapi tidak digunakan untuk membuat kesimpulan yang lebih luas."

Teknik Dokumentasi

Teknik dokumentasi adalah kegiatan mencari data mengenai hal-hal atau variabel yang berupa catatan, transkrip, buku, surat kabar, majalah, prasasti, notulen rapat, lengger, agenda, dan sebagainya (Arikunto,2006:231). Untuk memperoleh data pendukung yang dibutuhkan dari sumber yang dapat dipercaya maka digunakan teknik dokumentasi. Teknik dokumentasi berguna untuk memperoleh data tentang Volume Penjualan Pada Minimarekt Minamart'90.

III.2.3 Populasi Dan Sampel 
Adapun sumber data dalam penelitian sering disebut dengan populasi penelitian. Pengertian populasi menurut Husein Umar (2002:136) adalah : "populasi diartikan sebagai kumpulan elemen yang mempnyai karakteristik tertentu yang sama dan mempunyai kesempatan yang sama untuk dipilih menjadi anggota sampel".

Adapun pengertian sampel menurut Husein Umar (2002:136) adalah sebagai berikut : "sampel adalah bagian dari populasi”.

Didalam laporan Minamart'90 periode tahun 2013 sampai dengan 2015 terdapat data STD $=8.719$, artinya adalah jumlah pengunjung yang bertransaksi selama periode tiga tahu sejumlah 8.719 orang, sebagaimana diketahui bahwa, $=36$ bulan

1 tahun = 12 bulan, sehingga 3 tahun

$$
\begin{aligned}
\text { Rata-rata transaksi } & =8.719: 36 \\
& =242
\end{aligned}
$$

Sehingga jumlah rata-rata pengunjung atau konsumen yang bertransaksi adalah 242 orang perbulan dalam kurun waktu 3 tahun.

Penulis menggunakan angka ini sebagai jumlah populasi konsumen Minamart'90. Sehingga untuk menghitung sampel yang dibutuhkan dapat ditentukan dengan rumus yang di kemukakan oleh Slovin yang dikutip oleh Husein Umar (2002:141).

$$
\begin{aligned}
& \text { Rumus : } \\
& \mathrm{n}= \mathrm{N} /\left(1+\mathrm{N} . \mathrm{e}^{2}\right) \\
& \mathrm{n}= \text { Ukuran Sampel } \\
& \mathrm{N}= \text { Ukuran Populasi } \\
& \mathrm{E}= \text { Persen kelongaran } \\
& \text { ketidaktelitian karena kesalahan } \\
& \text { pengambilan sampel yang } \\
& \text { masih dapat ditolerir atau } \\
& \text { diinginkan. Penulis } \\
& \text { menggunakan } 10 \% .
\end{aligned}
$$

$$
\mathrm{n}=242 /(1+242 \times 0,1 \times 0,1) ; \mathrm{n}=
$$

70,76

Dengan batas kelonggaran kerena ketidak telitian sebesar $10 \%$, oleh karena itu dalam penelitian ini akan diambil sampel sebesar 100 orang/responden (pembulatan dari 70,76) yang seluruhnya berada di Kota Bandung.

Sedangkan untuk teknik pengambilan sampel menggunakan metode accidental sampling.Dimana menurut Arikunto (2002) accidental sampling adalah mengambil responden sebagai sampel berdasarkan kebetulan, yaitu siapa saja yang secara kebetulan bertemu dengan peneliti dapat digunakan sebagai sampel bila orang yang kebetulan ditemui cocok sebagai sumber data.

Kriteria Sampel

1) Konsumen yang berbelanja di Minamart

2) Frekuensi belanja dari 3 kali

\section{Teknik Analisis Data dan Pengujian Hipotesis}

Dalam penelitian ini, metode analisis yang digunakan untuk mengetahui pengaruh Kualitas Pelayanan terhadap Volume Penjualan adalah dengan menggunakan analisis statistik/uji statistik. Untuk mencari keeratan hubungan dan pengaruh antar variabel yang diteliti maka digunakan analisis regresi sederhana.

\section{Analisa Regresi}

Untuk mengetahui bagaimana pengaruh kedua variabel, peneliti menggunakan teknik Analisis Regresi Linier Sederhana. Analisis regresi linier digunakan untuk mengetahui perubahan yang terjadi pada variabel dependent (variabel Y), nilai variabel dependent 
berdasarkan nilai independent (variabel X) yang diketahui. Dengan menggunakan analisis regresi linier maka akan mengukur perubahan variabel terikat berdasarkan perubahan variabel bebas.

Dalam menganalisis data penelitian ini, peneliti menggunakan teknik analisis regresi linear sederhana. Analisis Regresi digunakan untuk mengetahui pengaruh Kualitas Pelayanan terhadap Volume Penjualan. persamaan regresinya adalah : $\hat{\mathbf{Y}}$ $=\mathbf{a}+\mathbf{b X} \quad$ (Sumber $:$ Sugiyono, 2009:204) Keterangan :

$\hat{\mathrm{Y}}=$ Subjek variabel terikat yang diprediksi (volume penjualan)

$\mathrm{X}=$ Subjek variabel bebas yang mempunyai nilai tertentu (kualitas kerja)

$\mathrm{a}=$ Bilangan konstanta regresi untuk $\mathrm{X}=0$ (nilai y pada saat $\mathrm{x}$ nol)

$\mathrm{b}=$ Koefisien arah regresi yang menunjukkan angka perubahan variabel Y

Berdasarkan persamaan diatas, maka nilai a dan $b$ dapat diketahui dengan menggunakan rumus least square sebagai berikut :

$$
\begin{aligned}
& \mathrm{a}=\frac{(\Sigma \mathrm{y})\left(\Sigma \mathrm{x}^{2}\right)-(\Sigma \mathrm{x})(\Sigma \mathrm{xy})}{\mathrm{n}\left(\Sigma \mathrm{x}^{2}\right)-(\Sigma \mathrm{x})^{2}} \\
& \dot{\mathrm{b}}=\frac{\mathrm{n}(\Sigma \mathrm{xy})-(\Sigma \mathrm{x})(\Sigma \mathrm{y})}{\mathrm{n}\left(\Sigma \mathrm{x}^{2}\right)-(\Sigma \mathrm{x})^{2}}
\end{aligned}
$$

Dimana : $\mathrm{n}=$ Jumlah Data Sampel

Setelah melakukan perhitungan dan telah diketahui nilai untuk a dan b, kemudian nilai tersebut dimasukan kedalam persamaan regresi sederhana untuk mengetahui perubahan yang terjadi pada variabel $Y$ berdasarkan nilai variabel $X$ yang diketahui. Persamaan regresi tersebut bermanfaat untuk meramalkan rata-rata variabel $Y$ bila $X$ diketahui dan memperkirakan rata-rata perubahan variabel Y untuk setiap perubahan X.

\section{Pengujian Hipotesis}

Menurut pendapat M. Iqbal Hasan (2004:54), "Pengujian hipotesis adalah suatu prosedur yang akan menghasilkan suatu keputusan, yaitu keputusan menerima atau menolak hipotesis tersebut". Hipotesis merupakan bagian penting dalam suatu penelitian, karena dengan adanya hipotesis, penelitian menjadi lebih terarah. Hipotesis dapat dijadikan sebagai petunjuk ke arah penyelidikan lebih lanjut. Oleh karena itu, hipotesis harus di uji kebenarannya melalui uji statistik.

Selanjutnya berdasarkan hasil regresi berganda tersebut, maka selanjutnya dapat dianalisis koefisien determinasi (R) yaitu koefisien determinasi parsial untuk mengukur secara terpisah dampak variabel bebas $\mathrm{X}$ terhadap variabel $\mathrm{Y}$, dengan bantuan program SPSS pada computer.

\section{Uji T (Uji Parsial)}

Untuk menguji hipotesis tersebut maka data yang diperoleh, di analisis dengan rumus uji „te. Uji ini digunakan untuk mengetahui apakah masing-masing variable bebasnya secara sendiri-sendiri berpengaruh secara signifikan terhadap variable terikatnya. Dimana $t_{\text {tabel }}>t_{\text {hitung, }}$ Ho diterima.Dan jika $t_{\text {tabel }}>t_{\text {hitung, }}$, Hi diterima.

Untuk menarik kesimpulan dari hipotesis dan untuk memperkuat didalam menganalisis data, peneliti menggunakan uji hipotesis dengan menggunakan program software SPSS for Windows. Data hasil Uji t bersumber pada output tabel One-Sample Test, kemudian pengujian dilakukan dengan membandingkan antara $t_{\text {hitung }}$ dan $t_{\text {table }}$ dengan langkah-langkah sebagai berikut:

1. Merumuskan hipotesis:

Apabila $\square=0$ maka $\mathrm{H}_{0}$ ditolak, itu berarti bahwa kualitas Pelayanan berpengaruh signifikan terhadap volume penjualan pada Minimarket Minamart'90 
Apabila $\square>0$ maka $\mathrm{H}_{0}$ diterima, itu berarti bahwa kualitas kerja tidak berpengaruh signifikan terhadap volume penjualan pada Minimarket Minamart'90

2. Menentukan $t_{\text {hitung }}$ dan signifikansi.

Dari output tabel One-Sample Test dapat dilihat hasil perolehan $t_{\text {hitung }}$ dan signifikansinya.

3. Menentukan table

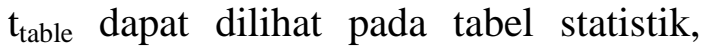
pada tingkat signifikansi 0,05 dengan $\mathrm{df}$ 1 (jumlah variabel bebas) $=1$, dan df 2 (n-k-1). $\mathrm{n}$ adalah jumlah data dan $\mathrm{k}$ adalah jumlah variabel independen.

4. Kriteria pengujian:

a. Jika $t_{\text {hitung }} \leq \mathrm{t}_{\text {table }}$ maka Ho diterima

b. Jika $t_{\text {hitung }}>$, $t_{\text {table }}$ maka Ho ditolak

c. Membuat kesimpulan, dengan Membandingkan antara $t_{\text {hitung }}$ dan $t_{\text {table }}$, dan kesimpulan didapat dari kriteria pengujian.

ANALISIS DATA DAN PEMBAHASAN

Kualitas pelayanan didefinisikan sebagai seberapa jauh perbedaan antarakenyataan dan harapan para pelanggan atas layanan yang mereka terima.Berdasarkan tabel 4.17 dapat diketahui dari 100 responden diperoleh keterangan :

1. dimensi kualitas pelayanan dengan bobot tinggi sebesar 3,3 terdapat pada dimensi kehandalan, jaminan dan empati.

2. dimensi kualitas pelayanan dengan bobot rendah sebesar 2,7 terdapat pada dimensi bukti fisik.

Distribusi variabel Y sebagaimana tergambar dalam tabel 3.2 laporan sestoran bulanan terdapat sejumlah 33 volume penjualan pada tahun 2013, 33 volume penjualan pada tahun 2014 dan 34 volume penjualan pada tahun 2015, sehingga secara keseluruhan terdapat 100 distribusi variabel Y (volume penjualan)

Uji Validitas

Menurut Arikunto dalam Duwi Priyatno (2009:17) bahwa apabila $r_{\text {hitung }}>r_{\text {tabel }}$, maka dapat dikatakan bahwa suatu instrumen adalah valid. Dari hasil pengujian validitas pada tabel 5.6 dapat dilihat bahwa keseluruhan item variabel penelitian mempunyai $r$ hitung $>r$ tabel pada tinggkat kesalahan $5 \% \quad(\alpha=0,05)$ dan $n=100$ diperoleh $\mathrm{r}$ tabel $=0,196$ maka dapat diketahui $r$ hasil tiap-tiap item > 0,196 sehingga dapat dikatakanbahwa keseluruhan item variabel penelitian adalah valid untuk digunakan sebagai instrumen dalam penelitian atau pertanyaan-pertanyaan yang diajukan dapat digunakan untuk mengukur variabel yang diteliti.

Uji Reliabilitas

Uji reliabilitas dimaksudkan untuk mengetahui adanya konsistensi alat ukur dalam penggunaannya atau dengan kata lain alat ukur tersebut mempunyai hasil yang konsisten apabila digunakan berkali-kali pada waktu yang berbeda. Menurut Arikunto (Duwi Priyanto, 2009:25) untuk menguji reliabilitas digunakan Teknik Alpha cronbach, dimana suatu instrument dapat dikatakan handal (reliabel)bila memiliki koefisien kehandalan atau alpha sebesar 0,5 atau lebih. Adapun hasil uji reliabilitas yang dilakukan terhadap intrumen penelitian ini dapat dijelaskan pada tabel berikut :

Tabel 1.Uji Reliability
Reliability Statistics
\begin{tabular}{|c|r|}
\hline $\begin{array}{c}\text { Cronbach's } \\
\text { Alpha }\end{array}$ & N of Items \\
\hline .741 & 15 \\
\hline
\end{tabular}


Koefisien Determinasi $\left(\mathbf{R}^{2}\right)$

Tabel 2. Koefisien Determinasi

Model Summary ${ }^{b}$

\begin{tabular}{|l|r|r|r|r|}
\hline Model & \multicolumn{1}{|c|}{$\mathrm{R}$} & R Square & $\begin{array}{c}\text { Adjusted R } \\
\text { Square }\end{array}$ & $\begin{array}{l}\text { Std. Error of } \\
\text { the Estimate }\end{array}$ \\
\hline 1 & $.881^{\mathrm{a}}$ & .776 & .067 & 908173.1057 \\
\hline
\end{tabular}

a. Predictors: (Constant), X

b. Dependent Variable: Y

Tabel 3.

Koefisien Analisi regresi Coefficients $^{\text {a }}$

\begin{tabular}{|c|c|c|c|c|c|}
\hline \multirow[b]{2}{*}{ Model } & \multicolumn{2}{|c|}{$\begin{array}{c}\text { Unstandardized } \\
\text { Coefficients }\end{array}$} & \multirow{2}{*}{$\begin{array}{c}\text { Standardized } \\
\text { Coefficients } \\
\text { Beta }\end{array}$} & \multirow[b]{2}{*}{$\mathrm{t}$} & \multirow[b]{2}{*}{ Sig. } \\
\hline & $\mathrm{B}$ & Std. Error & & & \\
\hline $\begin{array}{ll}1 & \text { (Constant) } \\
\text { X }\end{array}$ & $\begin{array}{r}38.496 \\
.881\end{array}$ & $\begin{array}{r}607608.532 \\
13785.374\end{array}$ & .881 & $\begin{array}{r}26.362 \\
2.843\end{array}$ & $\begin{array}{l}.000 \\
.005\end{array}$ \\
\hline
\end{tabular}

a. Dependent Variable: Y

$Y=38.496+0,881 X$

Pengujian Hipotesis

Hipotesis dalam penelitian tentang pengaruh Kualitas Pelayanan terhadap Volume Penjualan pada Minimarket Minamart'90 di bandung, yaitu:

"Terdapat pengaruh yang positif dan signifikan antara Kualitas Pelayanan terhadap Volume Penjualan pada Minimarket Minamart'90 di Bandung".

Teknik pengujian hipotesis dalam penelitian ini menggunakan teknik analisis regresi linier sederhana. Berdasarkan hipotesis penelitian diatas berlaku hipotesis statistik sebagaiberikut :
Ho : pop $\quad=0$ (tidak ada pengaruh yang signifikan antara kualitas pelyanan terhadap Volume penjualan)

Ha : pop $\neq 0$ (Terdapat pengaruh yang signifikan antara kualitas pelayanan terhadapVolume penjualan)

Berdasarkan tabel Coefficients diperoleh nilai Sig. $=0,005$. Karena digunakan taraf signifikansi 5\%, maka untuk nilai Sig $(0,005)<\alpha(0,05)$ maka dapat disimpulkan bahwa kita dapat menolak Ho dapat ditolak, artinya koefien regresi signifikan.

Hasil analisis regresi linier sederhana menggunakan program SPSS 23.0 for windows diperoleh nilai R2 sebesar 0,881 artinya variabel kualitas pelayanan dapat mempengaruhi volume penjualan sebesar $67 \%$. Adapun sisanya yaitu volume penjualan dapat dipengaruhi oleh faktor lainnya.

\section{SIMPULAN DAN SARAN}

Variabel kehandalan, jaminan dan empati berpengaruh signifikan terhadap volume penjualan pada minimarket Minamart'90. 
Variabel kehandalan, jaminan dan empati merupakan variabel yang mempunyai pengaruh paling dominan terhadap kepuasan konsumen karena variabel tersebut mempunyai nilai t-hitung yang lebih besar jika dibandingkan dengan variabel lain, yaitu sebesar 0.881 dan angka Sig. yang paling kecil yaitu sebesar 0,000.

Besarmya kontribusi pengaruh variabel kualitas pelayanan (kehandalan, ketanggapan, jaminan, empati dan bukti fisik) terhadap kualitas pelayanan pada minimarket Minamart'90 adalah sebesar 67 $\%$. Sementara sisanya sebesar $33 \%$ dipengaruhi oleh variabel lain yang tidak diteliti.

Untuk mendukung peningkatan jumlah konsumen minimarket Minamart'90 yang dicapai sebaiknya pihak manajemen perusahaan lebih menjaga kualitas pelayanan, pada aspek kehandalan, jaminan dan empati, sebab dimensi kualitas tersebut cukup dominan mempengaruhi volume penjualan pada minimarket Minamart'90 Bandung.

Untuk meningkatkan Aspek-aspek daya tanggap dan bukti fisik pada dimensi kualitas pelayanan, seperti menanggapi keluhan pelanggan, area parkir yang leluasa, AC dalam ruangan untuk mempersejuk ruangan agar lebih nyaman.

\section{DAFTAR PUSTAKA}

Irwan, Rumus dan datadalamanalisis statistika.

Alfabeta. Sahaja, 2014.

Bandung:

Kasmir,S.E., M.M. Dr. dan Jakfar, S.E., M.M. Studi Kelayakan Bisnis Edisi Revisi,Prenada Media, 2012.

Sinambela, Lijan Poltak. Reformasi Pelayanan Publik, Jakarta: PT. Bumi Aksara, 2010.

Kusnadi. Teori Akuntansi. Universitas Brawijaya Malang. 2009,
Sugiyono. Metode Penelitian Kualitatif Kuantitatif dan $R \& D$, Bandung: CV Alfabeta.,2008

Kotler, Philip \& Keller, Kevin Lane. Manajemen Pemasaran. Edisi tiga belas Bahasa Indonesia. Jilid 1 dan 2. Jakarta : Salemba Empat. 2007.

Arief, Muhtosim. Pemasaran Jasa dan Kualitas Pelayanan. Malang: Banyumedia, 2007.

Swastha, Basu. Manajemen Pemasaran Modern, Yogyakarta: Liberty, 2007.

Prof. J. Supranto, MA., ECONOMIC REVIEW, Bisnis Berorientasi Pasar akan menguntungkan Pelanggan, Karyawan dan Pemegang saham serta meningkatkan Laba, 2006

Supranto. Pengukuran Tingkat Kepuasan Pelanggan. Cetakan Ketiga. Rineka Cipta: Jakarta 2006.

Tjiptono, Fandy. Prinsip-Prinsip Total Quality Service, Yogyakarta : Andi, 2005

Kotler, Philip. Manajemen Pemasaran, Edisi 11 jilid 1 dan 2 Pemasaran, Jakarta, PT. Indeks,Jakarta. 2005.

Kotler, Philip. Manajamen Pemasaran, Jilid 1 dan 2. Jakarta: PT. Indeks, 2005.

Sudarmanto, R. Gunawan, Analisis Regresi Linear Berganda dengan SPSS, Yogyakarta: Graha Ilmu, 2005.

Ratminto dan Atik Winarsih. Manajemen Pelayanan. Pustaka Pelajar: Yogyakarta, 2005

Fandy Tjiptono. Strategi Pemasaran. Yogyakarta: Andi Offset. 2005

A.Karim, Bank Islam Analisis Fiqih dan Keuangan, PT. RajaGrafindo Persada., Jakarta.,2004

Gerson, Richard. F.. Mengukur Kepuasan Pelanggan, Jakarta, PPM., 2004.

Sugiyono, Metode Penelitian Bisnis, Bandung: CV. Alvabeta, 2003. 
Alimiyah dan Padji , Kamus Istilah Schiffman, Leon G. Consumer Behavior; Akuntansi Suatu Pengantar, Consumer. Learning; 2000 2003.

Usmara, A. (ed.), Strategi Baru Manajemen Pemasaran, Yoyakarta: Amara Books, 2003.

Lupiyoadi, Rambat. 2001. Manajemen Pemasaran Jasa. Edisi Pertama. Salemba Empat: Jakarta, 2001.

Tjiptono, Fandy dan Diana, Anastasia, Total Quality Management.

Yogyakarta, Andi,2003

Basu Swasta dan Dharmesta. Manajemen Pemasaran, Analisis Perilaku Konsumen. Yogyakarta : Penerbit BPFE. 2003

Arikunto, Suharsimi, Prosedur Penelitian Suatu Pendekatan Praktek, Jakarta: Rineka Cipta, 2002.

Tjiptono, Fandy, Strategi Pemasaran, Yogyakarta: ANDI Offset, 2001 Fandy, Tjiptono. Manajemen Jasa. Edisi Kedua, Yogyakarta : Liberty, 2001.

Swastha, Basu Dharmesta dan T. Hani Handoko, Manajemen Pemasaran: Analisa Perilaku Konsumen, Edisi III, Yogyakarta: BPFE, 2000

Kotler, Philip dan Armstrong Gary. DasarDasar Pemasaran-Jilid 2 Edisi 6, Jakarta: Intermedia,1996.

Groonroos, Christian, Management and Marketing, Massachussets, Toronto : Lexington Books, 1990.

Stanton, William J., Prinsip Pemasaran, jilid 1, Alih bahasa Yohanes Lamarto, Jakarta: Erlangga, 1984. 